\title{
ГЕОЛОГО-ГИДРОГЕОЛОГИЧЕСКИЕ УСЛОВИЯ ПОДЗЕМНОГО ЗАХОРОНЕНИЯ ПРОМСТОКОВ НА ГАЗОВЫХ МЕСТОРОЖДЕНИЯХ ЗАПАДНОЙ СИБИРИ
}

Севастьянов О.M., Захарова E.E. (ООО «ВолгоУралНИПИгаз»)

Резгоме. В Западной Сибири имеются очень благоприятные условия для подземного захоронения промстоков (ПЗП). Хоропим поглощающим горизонтом, удовлетворяющим всем требованиям для ПЗП, является регионально развитая альб-сеноманская водоносная толща, подстилающая сеноманские газовые залежи многих месторождений Тюменского Севера. Положительњый многолетний опыт закачки промстоков в этот горизонт позволяет рекомендовать его использование в этих целях в более пироких масштабах.

Oписание результатов. На газовых месторождениях Западной Сибири вместе с газом извлекаются попутные пластовые воды. Из-за повышенной минерализации они не поддаются очистке и не подлежат сбросу на рельеф или в открытые водоемы. Попутные воды представляют собой основной объем загрязненных промстоков, требующих ликвидация. Основным методом обезврежсивания таких стоков, предотвращающим загрязнение окружающей среды, является их подземное захоронение в глубокозалегағощие водоносные горизонты, называемые поглощающими.

На газовых месторождениях Тюменского Севера имеются исключительно благоприятные геолого-гидрогеологические условия для ПЗП, которые состоят в следуюшем. На всех месторождениях региона основным объектом разработки являются сеноманские газовые залежи, залегающие в песчаных породах в интервале глубин 850-1300 м. Они подстилаются мошной водонапорной системой альбсеноманских песчаных отложений (покурская свита). Покрышкой газовых залежей служат глижы верхнего мела и палеогена. В самой верхней части разреза до глубины 400-450 м развиты многолетнемерзлые породы. В южной части региона мерзлота двухслойная. В ней выделяются надмерзлотный, межмерзлотный водоносные горизонты и сквозные талики, к песчаным породам которых приурочены пресные подземные воды, использующиеся для хозяйственно-питьевого и производственного водоснабжения. На севере региона мерзлота сплошная, водоносные горизонты с питьевой водой здесь отсутствуют и для водоснабжения используется вода открытых водоемов.

Для подземного захоронения промстоков используется альб-сеноманская водонапорная система, подстилаюшая газовые залежи, которая отвечает всем требованиям, предъявляемым к ПЗП. Пластовая вода альб-сеноманских отложений имеет минерализацию 16-18 г/л и не пригодна для хозяйственно-питьевого водоснабжения. Коллекторские свойства пород поглощающего горизонта высокие (пористость 25-30\%, проницаемость не менее $0,5 \cdot 10^{-}$ $12 \mathrm{M}^{2}$ ), qто обеспечивает и высокую приемистость скважин. Поглошающий горизонт надежно изолирован от верхних водоносных горизонтов с питьевой водой и открытых водоемов региональным глинистым водоупором, развитым над сеноманскими

газовыми залежами, и мощной вышележащей толщей многолетнемерзлых пород. ПЗП осуществляется в контуре месторождений под залежи на глубину 990-1600 м (чаще 1100-1400 м), которая оптимальная и вполне приемлема в техникоэкономическом отношенин.

Особо благоприятным фактором захоронения промстоков в альб-сеноманскую водонапорную систему является то, что в ней несмотря на закачку сточных вод происходит снижение пластового давления из-за отбора газа из залежей. Объемов захороняемых стоков недостаточно для заполнения депрессионньх воронок, развиваюшихся в водонапорной системе, гидродинамически связанной с разрабатываемыми газовыми залежами.

В наиболее широком масштабе ПЗП производится на Уренгойском месторождения, где оно началось в 1979 г. Промстоки захороняются на всех 15-ти установках комплексной подготовки газа (УКПГ), на заводе по переработке газового конденсата, на двух центральных пунктах сбора нефти (ЦПС), на базе по снабжению нефтепродуктами и интибиторами. Всего на месторождении имеются 42 поглощающие скважины, в которые захоронено 6олее 25 млн.м ${ }^{3}$ стоков. Суточные объемы закачки на разных УКПГ и ЦПС составляют $70-220 \mathrm{~m}^{3}$, на заводе - 500-600 $\mathrm{m}^{3}$, на базе - $50 \mathrm{~m}^{3}$, а суммарно на всех объектах Уренгойского комплекса в последние годы закачивается около $2500 \mathrm{~m}^{3} /$ сут промстоков.

На Ямбургском месторождении пробурено 30 поглопаюпих скважин: по 2-3 скважины на всех 10ти действующих УКПГ и 4 скважины на промзоне пос. Ямбург. Расход закачки составляет 100-150 $\mathrm{M}^{3} /$ сут на одну скважину.

На Вынтапуровском месторождении промстоки закачиваются с 1992 г в скв. № 301, расположенную недалеко от УКПГ и переоборудованную в поглопаюцую из пьезометрической. В период с 1992 г по 2002 г объем закачки промстоков состав-

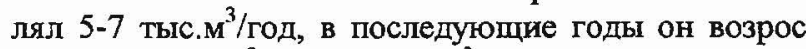
до $15-17$ тыс. ${ }^{3} /$ год $\left(43-47 \mathrm{~m}^{3} /\right.$ сут). Всего в скв. № 301 закачано более 100 тыс.м $^{3}$ промстоков.

На Комсомольском месторождении захоронение промстоков осуществляется с 1997 г. Для этих целей пробурено 5 скважин, объемы закачки стоков в которые составляют от 2 до $125 \mathrm{~m}^{3} /$ сут. Всего на Комсомольском месторождении захоронено около 215 тыс. ${ }^{3}$ стоков.

ПЗП в альб-сеноманский поглощающий горизонт также осуществляется на Западно-Таркосалинском, Ямсовейском, Юбилейном и некоторых других газовых месторождениях.

Заключение. Накопленный положительный опыт позволяет рекомендовать регионально развитый в Западной Сибири альб-сеноманский поглощающий горизонт для широкого использования для целей ПЗП не только нефтегазового комптекса, но и предприятий других отраслей народного хозяйства. 